\title{
Arahan Penataan Permukiman Kumuh di Kelurahan Kedungcowek Surabaya Menggunakan Konsep Land Readjustment
}

\author{
Amirul Ardi dan Dian Rahmawati \\ Departemen Perencanaan Wilayah dan Kota, Fakultas Arsitektur, Desain dan Perencanaan, \\ Institut Teknologi Sepuluh Nopember (ITS) \\ e-mail:d_rahmawati@urplan.its.ac.id
}

\begin{abstract}
Abstrak - Salah satu kawasan prioritas kumuh di Kota Surabaya yaitu permukiman nelayan yang berada di Pantai Utara Surabaya, tepatnya di Kelurahan Kedungcowek. Kekumuhan permukiman Kedungcowek ditunjukkan dengan belum jelasnya legalitas lahan hunian, buruknya kondisi fisik bangunan serta masih kurangnya ketersediaan sarana umum kebutuhan permukiman nelayan yang berdampak pada kondisi prasarana dasar yang tidak sesuai dengan standar teknis penunjang permukiman. Tujuan dari penilitan ini adalah merumuskan skenario penataan permukiman kumuh dengan konsep Land Readjusment. Penelitian ini melalui tiga tahap analisis. Tahap pertama dengan anailsis statistik deskriptif dan mapping untuk menganalisisi karakteristik permukiman kumuh nelayan di Kedungcowek. Selain itu teknik analisis Skoring dan Theoritical Descriptive digunakan untuk menganalisis faktor-faktor yang berpengaruh dalam penerapan konsep land readjustment. Selanjutnya hasil analisis dari dua tahap sebelumnya digunakan untuk perumusan arahan penataan permukiman kumuh nelayan dengan konsep land readjustment dengan analisis deskriptif. Hasil penelitian ini yaitu skenario pembagian lahan atas kesepatakan pemilik lahan terkait kontribusi lahan yang terdiri dari tiga pilihan yang didapatkan dari kesepakatan dengan pemilik lahan. Adapun ketiga opsi tersebut $75 \%$ untuk pemilik lahan dan $25 \%$ untuk kepentingan umum, $70 \%$ untuk pemilik lahan dan $30 \%$ untuk kepentingan umum, serta $60 \%$ untuk pemilik lahan dan $40 \%$ untuk kepentingan umum. Dengan kontribusi lahan dari masyarakat, maka akan tercukupinya kebutuhan sarana umum penunjang permukiman nelayan, selain itu juga didapatnya lahan cadangan yang nantinya dapat dimanfaatkan. Tata letak bangunan menjadi lebih proposional dan kondisi fisik bangunan menjadi permanen serta kejelasan status kepemilikan lahan menjadi sertifikat hak milik.
\end{abstract}

Kata Kunci-Konsep Land Readjustment, Penataan Permukiman Kumuh, Skenario Pembagian Lahan.

\section{PENDAHULUAN}

$\mathrm{P}$ ERMUKIMAN kumuh merupakan salah satu permasalahan yang dihadapi oleh kota-kota berkembang di dunia termasuk Indonesia, permukiman kumuh merupakan bagian yang terabaikan dalam pembangunan perkotaan. Pada tahun 2015, kawasan permukiman kumuh di Indonesia telah mencapai luas $38.341 \mathrm{Ha}$ atau sekitar 10\% dari total kawasan permukiman.. Jika kondisi ini tidak segera ditangani, maka dengan kecepatan pertambahan yang konstan, kebutuhan akan perumahan hingga tahun 2025 diperkirakan mencapai lebih dari 30 juta unit baru yang apabila tidak terpenuhi akan menyebabkan permukiman kumuh yang meningkat akibat kepadatan penduduk.

Sebagai kota metropolitan terbesar kedua di Indonesia sekaligus pusat ekonomi di Provinsi Jawa Timur, Kota Surabaya memiliki angka laju pertumbuhan penduduk per tahun sebesar $0,52 \%$. [1].Tingginya laju pertumbuhan dan kepadatan penduduk di Kota Surabaya tidak diimbangi dengan ketersediaan tempat tinggal yang memadai, khususnya bagi masyarakat yang berpendapatan rendah. Sehingga dengan permasalahan tersebut menimbulkan adanya permukiman kumuh [2]. Berdasarkan Surat Keputusan Walikota Surabaya Nomor : 188.45/ 143/ 436.1.2/ 2015 Tentang Kawasan Prioritas Peningkatan Kualitas Perumahan dan Permukiman tahun 2015, Di Kota Surabaya ditetapkan 26 Kelurahan dari 18 Kecamatan dengan total luasan 145, 89 Ha menjadi kawasan permukiman kumuh, sedangkan di tahun 2017 menjadi $299 \mathrm{Ha}$ [3]. Dari semua kawasan kumuh yang ada, pemerintah Kota Surabaya menetapkan kawasan prioritas peningkatan kualitas perumahan dan permukiman yang didasarkan pada Kajian Penentuan Kawasan Prioritas Penataan dan Peningkatan Kualitas Lingkungan Perumahan dan Permukiman Di Kota Surabaya yang dilakukan oleh Badan Perencanaan dan Pembangunan Kota Surabaya. Kawasan prioritas ini merupakan kawasan permukiman yang terdapat di Kota Surabaya karena potensi, persoalan, dan karakteristik yang dimilikinya perlu untuk ditangani terlebih dahulu [4].

Salah satu kawasan prioritas kumuh di Kota Surabaya yaitu permukiman nelayan yang berada di Pantai Utara Surabaya, tepatnya di Kelurahan Kedungcowek Kecamatan Bulak. Kawasan permukiman kumuh di Kelurahan Kedungcowek berdasarkan SK Walikota 2015 berada di RW 1 RT 4, namun kawasan tersebut sudah tidak lagi kumuh sehingga lokasi permukiman kumuh ini mengalami perubahan yaitu terletak di RW 2 dan RW 3. Diidentifikasi dari kondisi ekssting permukiman Kedungcowek, kekumuhan di permukiman Kedungcowek ditunjukkan dengan belum jelasnya legalitas lahan hunian, buruknya kondisi fisik bangunan serta masih kurangnya ketersediaan sarana umum kebutuhan permukiman nelayan yang berdampak pada kondisi prasarana dasar yang tidak sesuai dengan standar teknis penunjang permukiman, maka dari itu perlunya penataan kembali permukiman kumuh menggunakan konsep land readjustment.

Model land readjustment adalah teknik di mana sekelompok pemilik lahan yang ada di perkotaan, digabungkan dalam satu 
kemitraan untuk perencanaan terpadu. Pelayanan dan pembagian tanah dilakukan dengan membagi seluruh biaya dan keuntungan antara pemilik tanah [5]. Penataan permukiman kumuh menggunakan metode land readjustment lahan menjadikan pemilik tanah merelakan sebahagian lahannya untuk untuk diatur, dibangun sarana dan prasarana dasar agar lingkungan lebih tertata dan dipakai untuk fasilitas lingkungan atau fasilitas umum untuk memenuhi kelayakan suatu kawasan permukiman. Pengaturan lahan secara keseluruhan disesuaikan dengan proporsi yaitu 60\% untuk pemilik dan $40 \%$ untuk fasilitas umum ataupun proporsi lain sesuai kesepakatan, dalam proses perencanaannya dilakukan bersama-sama dengan persetujuan semua pihak [6]. Maka dari itu skenario penataan permukiman kumuh menggunakan metode land readjustment diharapkan dapat memperbaiki kehidupan masyarakat Kedungcowek

\section{METODE PENELITIAN}

\section{A. Jenis dan Pendekatan Penelitian}

Pendekatan yang digunakan dalam penelitian ini adalah pendekatan rasionalistik. Penelitian ini merupakan penelitian terapan dengan jenis penelitian mixed method yaitu kualitatif dan kuantitatif.

\section{B. Variabel Penelitian}

Variabel penelitian yang digunakan dalam merumuskan arahan penataan permukiman kumuh kelurahan Kedungcowek antara lain prasarana yang terdiri jalan, drainase, sanitasi, air bersih, persampahan, sarana penunjang permukiman nelayan, mata pencaharian, kepadatan bangunan, kondisi bangunan, status kepemilikan lahan, kesesuaian peruntukan dan luas persil lahan.

\section{Menganalis Karakteristik Permukiman Kumuh Di} Kelurahan Kedungcowek

Analisis statistik deskriptif digunakan untuk mendeskripsikan hasil identifikasi karakteristik permukiman kumuh Kelurahan Kedungcowek. Pengumpulan data dilakukan melalui proses observasi lapangan mengenai kondisi faktual dan juga dari penyebaran kuesioner kepada masyarakat penghuni permukiman kumuh Kelurahan Kedungcowek.

Selanjutnya dilakukan analisis klaster menggunakan hasil perhitungan SPSS, analisis ini bertujuan untuk pengelompokan berdasarkan kesamaan karakteristik yang dimiliki. Dalam sasaran ini juga dilakukan pemetaan, pemetaan bertujuan untuk memudahkan dalam melakukan interpretasi. Adapun output dari analisis ini yaitu peta pembagian klaster permukiman kumuh Kelurahan Kedungcowek.

D. Menganalisis Faktor Yang Berpengerauh Dalam Penerapan Konsep Land Readjustment Di Permukiman Kumuh Kelurahan Kedungcowek.

Dalam penentuan faktor yang berpengaruh dalam penerapan konsep Land Readjustment dilakukan pengisian kuesioner oleh stakeholder dengan teknik purposive sampling. Setelah mentabulasi dan menghitung hasil skoring masing-masing variabel berdasarkan kuesioner, selanjutnya nilai bobot variabel yang dihasilkan akan dijadikan faktor yang berpengaruh pada penerapan konsep land readjustment di permukiman kumuh Kelurahan Kedungcowek. Proses diskusi variabel menjadi faktor dilakukan dengan proses analisis theoritical descriptive [7]. Analisis theoritical descriptive merupakan analisis yang dilaksanakan guna memberikan gambaran mengenai objek studi secara mendalam disertai dengan pambahasan yang disesuaikan dengan teori terkait.

\section{E. Merumuskan Skenario Penataan Permukiman Kumuh Dengan Konsep Land Readjutment Di Kelurahan Kedungcowek}

Dari faktor-faktor yang berpengaruh dalam penerapan konsep Land Readjustment dapat diidentifikasi aspek apa saja yang akan dirumuskan dalam arahan penataan permukiman kumuh yang selanjutnya akan dilakukan penjaringan kesepakatan dengan pemilik lahan mengenai mekanisme implementasi konsep Land Readjustment sendiri. Proses penjaringan kesepakatan sendiri dilakukan dengan menyebar kuesioner mengenai pilihan-pilihan mekanisme implementasi konsep yang diterapkan. Dari kuesioner tersebut masyarakat pemilik lahan dapat memilih opsi yang diinginkan dalam penerapan konsep ini, diperkuat juga dengan hasil wawancara maka dapat dirumuskanlah skenario penataan permukiman kumuh Kelurahan Kedungcowek menggunakan konsep Land Readjustment.

\section{HASIL DAN DISKUSI}

\section{A. Analisis Karakteristik Permukiman Kumuh Di Kelurahan Kedungcowek}

Analisis ini diawali dengan mengidentifikasi karakteristik permukiman kumuh Kelurahan Kedungcowek. Identifikasi karakteristik dilakukan dengan observasi lapangan dan kuisioner ke masyarakat penghuni permukiman.

a) Kepemilikan Lahan

Tabel 1.

Status Kepemilikan Lahan Permukiman kumuh Kedungcowek

\begin{tabular}{cc}
\hline \hline Status Kepemilikan Lahan & Jumlah Persil \\
\hline Petok D & 85 \\
Sertifikat Hak Milik (SHM) & 2 \\
Tidak Bersertifikat & 1 \\
Total & 88 \\
\hline \hline
\end{tabular}

Lahan masyarakat merupakan warisan dari leluhur serta ada beberapa yang menjadi tangan kedua setelah membelinya dari orang lain. Faktor finansial yang rendah dan ketidakpastian hukum mengenai isu penggusuran menjadikan masyarakat menjadi enggan untuk mengurus sertifikat hak milik (SHM).

b) Kondisi Fisik Bangunan

Tabel 2.

Kondisi Jenis Bangunan Permukiman kumuh Kedungcowek

\begin{tabular}{cc}
\hline \hline Kategori & Jumlah Persil \\
\hline Permanen & 27 \\
Semi Permanen & 23 \\
Non Permanen & 38
\end{tabular}


Total

88

Berdasarkan hasil rekapitulasi kuesioner, diidentifikasi bahwa dari 88 persil, sebanyak 27 persil (30\%) merupakan bangunan permanen, 23 persil (27\%) tergolong semi permanen dan 38 persil (43\%) lainnya terindikasi bangunan non permanen.

\section{c) Luas Persil Lahan}

Luas persil lahan di permukiman nelayan Kelurahan Kedungcowek bervariasi dari $45 \mathrm{~m}^{2}$ hingga $80 \mathrm{~m}^{2}$. Sebanyak 38 persil memiliki luas $45 \mathrm{~m}^{2}$ (43\%), 26 persil dengan luas 65 $\mathrm{m}^{2}(30 \%), 24$ persil lainnya dengan luas $80 \mathrm{~m}^{2}(27 \%)$.

Tabel 3.

Luas Persil Lahan Permukiman kumuh Kedungcowek

\begin{tabular}{cc}
\hline \hline Luas Lahan & Jumlah Persil \\
\hline $45 \mathrm{~m}^{2}$ & 38 \\
$65 \mathrm{~m}^{2}$ & 26 \\
$80 \mathrm{~m}^{2}$ & 24 \\
Total & 88 \\
\hline \hline
\end{tabular}

d) Mata Pencaharian

Data mengenai mata pencaharian digunakan untuk mengidentifikasi jumlah nelayan yang tinggal di Kelurahan Kedungcowek, selain nelayan ditemukan juga masyarakat dengan mata pencaharian buruh dan wiraswasta.

Tabel 4.

Jenis Mata Pencaharian Penduduk Permukiman Kedungcowek

\begin{tabular}{cc}
\hline \hline Mata Pencaharian & Jumlah \\
\hline Nelayan & 59 \\
Buruh & 20 \\
Wiraswasta & 9 \\
Total & 88 \\
\hline \hline
\end{tabular}

Sumber : Hasil Analisis, 2018

e) Kepadatan Bangunan

Lahan yang tertutup yaitu $5728 \mathrm{~m}^{2}$ atau $87 \%$ dari total keseluruhan area sehingga hanya menyisakan 13\% saja untuk ruang terbuka. Hal itu mengindikasikan bahwa lokasi tersebut termasuk area berkepadatan tinggi. Dilihat dari standar kepadatan bangunan berdasarkan jumlah unit bangunan per hektarnya, pada permukiman nelayan Kedungcowek kepadatan bangunan per unitnya yaitu 155 unit/ha. Hal itu semakin menguatkan indikasi bahwa lokasi permukiman ini tergolong berkepadatan tinggi.

f) Kesesuaian Peruntukan Lahan

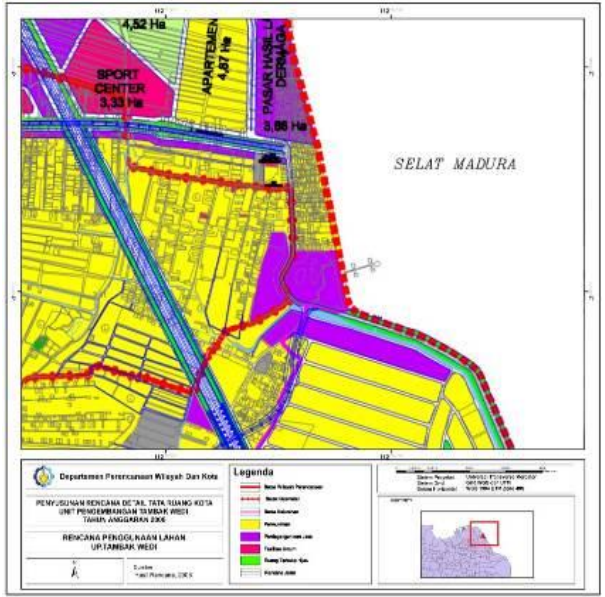

Gambar 1. Peta Rencana Penggunaan Lahan RDTRK UP Tambak Wedi.

Dalam dokumen RDTRK UP Tambak Wedi, daerah permukiman nelayan Kelurahan Kedungcowek pada lokasi studi direncanakan untuk peruntukan permukiman. Sehingga kondisi eksisting yang ada sudah sesuai dengan dokumen perencanaan.

g) Kondisi Prasarana

Tabel 5

Kondisi Prasarana Permukiman Kumuh Kedungcowek

\begin{tabular}{|c|c|}
\hline Prasarana & Keterangan \\
\hline Persampahan & $\begin{array}{l}\text { Sistem pembuangan sampah di permukiman nelayan Kedungcowek } \\
\text { sudah baik, hampir semua rumah sudah memiliki tempat sampah } \\
\text { pribadi. Pengangkutan sampahnya pun rutin selama 2-3 hari sekali }\end{array}$ \\
\hline Drainase & $\begin{array}{l}\text { Kondisi draniase di lingkungan permukiman Kedungcowek sudah } \\
\text { cukup baik, dengan sistem drainase tertutup sudah mampu } \\
\text { mengalirkan limpahan air dengan baik menuju laut. }\end{array}$ \\
\hline Sanitasi & $\begin{array}{l}\text { Kebutuhan sanitasi di permukiman nelayan Kedungcowek sudah } \\
\text { baik. Meskipun ada yang masih menggunakan sumur, namun } \\
\text { mayoritas rumah penduduk sudah memiliki MCK pribadi. Bagi } \\
\text { rumah yang belum memiliki MCK pribadi biasanya untuk } \\
\text { memenuhi kebutuhan sanitasi mereka menggunakan fasilitas MCK } \\
\text { umum yang berada di Balai RW atau pun menumpang di tetangga } \\
\text { mereka. }\end{array}$ \\
\hline Air Bersih & $\begin{array}{l}\text { Permukiman nelayan Kedungcowek telah dilewati pipa PDAM, } \\
\text { tetapi terdapat beberapa rumah yang memilih tidak memasang } \\
\text { intalasi PDAM karena keterbatasan biaya. Dalam memenuhi } \\
\text { kebutuhan mandi dan cuci, masyarakat mengandalkan air sumur. } \\
\text { Air sumur di Kedungcowek kondisinya jernih, tidak berbau dan } \\
\text { tidak berasa. Maka darinya masyarakat yang belum menggunakan } \\
\text { PDAM merasa masih belum terdesak untuk berganti sumber air } \\
\text { bersih ke PDAM. }\end{array}$ \\
\hline Jalan & $\begin{array}{l}\text { Kondisi perkerasan jalan di lingkungan merupakan paving. Lebar } \\
\text { jalan sekitar } 1,5-2 \text { meter menyulitkan arus sirkulasi barang dan } \\
\text { orang. Adanya hambatan samping seperti terpakirnya motor } \\
\text { masyarakat, penyimpanan barang-barang nelayan dan penjemuran } \\
\text { ikan sehingga makin membuat sempit badan jalan. }\end{array}$ \\
\hline
\end{tabular}

h) Kondisi Sarana Penunjang Permukiman Nelayan

Tabel 6.

Kondisi Sarana Permukiman Kumuh Kedungcowek

\begin{tabular}{|c|c|}
\hline Sarana & Keterangan \\
\hline $\begin{array}{l}\text { Tempat } \\
\text { Pelelangan } \\
\text { Ikan (TPI) }\end{array}$ & $\begin{array}{l}\text { Di Surabaya tempat pelelangan ikan masih belum terbangun, hanya } \\
\text { ada berupa pasar atau sentra ikan. Tempat pelelangan ikan di } \\
\text { Surabaya sendiri masih dalam proses untuk penentuan titik lokasi } \\
\text { pembangunan bersamaan dengan penentuan pangkalan pendaratan } \\
\text { ikan (PPI). } \\
\text { Belum adanya tempat pelelangan ikan berdampak pada distribusi } \\
\text { penjualan hasil tangkapan nelayan yang harus melalui perantara } \\
\text { pihak ketiga untuk menjual hasil tangkapan dan olahan ikan. Hal itu } \\
\text { tentunya merugikan nelayan yang tidak memiliki akses langsung } \\
\text { dalam menjual hasil tangkapan dan olahan ikan. }\end{array}$ \\
\hline $\begin{array}{c}\text { Tempat } \\
\text { Penjemuran } \\
\text { Ikan }\end{array}$ & $\begin{array}{l}\text { Keterbatasan lahan kosong menjadi faktor utama mengapa nelayan } \\
\text { akhirnya terpaksa menjemur hasil tangkapan ikannya di bahu jalan } \\
\text { ataupun di atap rumah. Selain mengganggu arus sirkulasi jalan, } \\
\text { dampak dari penjemuran ikan pada sembarang tempat yaitu bibit } \\
\text { penyakit yang dapat timbul diakibatkan banyaknya lalat pada } \\
\text { sekitar lokasi penjemuran. }\end{array}$ \\
\hline $\begin{array}{c}\text { Gudang } \\
\text { Penyimpanan }\end{array}$ & $\begin{array}{l}\text { Gudang tempat penyimpanan peralatan tangkap di Kelurahan } \\
\text { Kedungcowek hanya terletak di balai RW, itupun tidak semua } \\
\text { penyimpanan peralatan tangkap dapat tertampung akibat dari } \\
\text { terbatasnya gudang penyimpanan. Hal itu menyebabkan nelayan } \\
\text { biasa menyimpan peralatan tangkapnya di depan atau samping rumah } \\
\text { dikarenakan keterbatasan ruang di dalam rumah nelayan tersebut. } \\
\text { Selain menyimpan dekat dengan rumah, beberapa nelayan juga } \\
\text { menaruh peralatan tangkapnya di sepanjang jalan dekat pinggir } \\
\text { pantai. }\end{array}$ \\
\hline
\end{tabular}

Selanjutnya dilakukan pengelompokkan permukiman nelayan Kedungcowek berdasarkan kesamaan karakteristik. Dalam pemetaan ini beberapa variabel hanya diidentifikasi dan tidak dimasukkan dalam proses analisis cluster dikarenakan pada kondisi eksisting memiliki kondisi yang sama. Sehingga variabel yang digunakan dalam pemetaan yaitu karakteristik luas persil lahan, status kepemilikan lahan, kondisi bangunan 
dan ketersediaan sumber air bersih. Berdasarkan hasil analisis menggunakan SPSS pengelompokkan terdiri dari dua klaster.

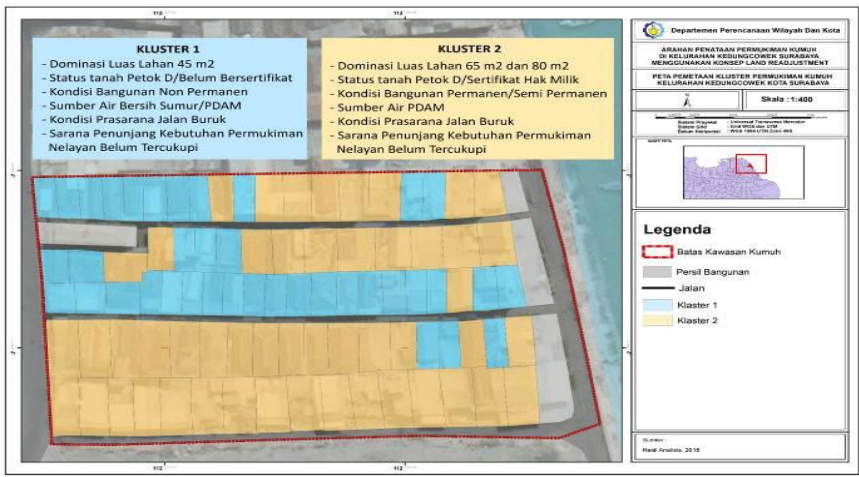

Gambar 2. Peta Pembagian Kluster Permukiman Kumuh Kedungcowek.

\section{Klaster 1}

Pada klaster ini karakteristik kondisi bangunan didominasi bangunan non permanen dengan kontruksi bangunan beratap seng, berdinding papan dan berlantai semen atau tanah. Mayoritas penduduk di klaster 1 menempati lahan dengan status kepemilikan petok $\mathrm{D}$, namun masih ada juga rumah yang belum bersertifikat. Luas persil lahan di klaster ini didominasi lahan persil seluas $45 \mathrm{~m}^{2}$. Kondisi prasarana dasar seperti sanitasi, drainase sudah cukup baik namun untuk penyediaan sumber air bersih masih ada yang menggunakan sumur karena ketidakmampuan memasang sambungan PDAM. Bahkan masih ada yang belum mempunyai MCK pribadi. 2. Klaster 2

Klaster ini memiliki luas persil lahan pada $65 \mathrm{~m}^{2}$ dan $80 \mathrm{~m}^{2}$. Kondisi prasarana dasarnya pun tergolong baik, dilihat dari darinase, sanitasi, persampahan, dan sumber air bersih yang sudah tersambung dengan PDAM secara merata. Karakteristik kondisi bangunan sendiri di dominasi bangunan permanen dengan kontruksi bangunan beratap genteng atau sebagian seng, berdinding batu bata, dan berlantai keramik. Untuk status kepemilikan lahannya didominasi dengan Petok D namun ada juga yang sudah memiliki Sertifikat Hak Milik (SHM). Mata pencaharian penduduk sendiri mayoritas bekerja sebagai nelayan.

B. Analisis Faktor Yang Berpengaruh Dalam Penerapan Konsep Land Readjustment Di Permukiman Kumuh Kelurahan Kedungcowek.

Dalam menganalisis faktor-faktor diawali dengan menskoring variabel-variabel terpilih dalam kajian pustaka yang berpengaruh dalam penelitian. Variabel-variabel yang digunakan yaitu ketersediaan prasarana penunjang permukiman, ketersediaan sarana penunjang permukiman nelayan, mata pencaharian, kondisi bangunan permukiman, tingkat kepadatan bangunan permukiman, status kepemilikan lahan permukiman, kesesuaian kegiatan berdasarkan rencana zonasi peruntukan dan luas persil lahan.

Analisis yang dilaksanakan bedasarkan hasil kuisioner dimana variabel-variabel yang ada dibobotkan. Berikut adalah tabel hasil rekapitulasi dan persentase nilai variabel yang dianggap berpengaruh oleh para stakeholder.

Tabel 7.

Hasil Skoring Variabel yang Berpengaruh Dalam Penerapan Konsep Land Readjustment

\begin{tabular}{ccccc}
\hline \hline \multirow{2}{*}{ Variabel } & \multicolumn{3}{c}{ Tingkat Pengaruh } & \multirow{2}{*}{ Modus } \\
\cline { 2 - 5 } & 1 & 2 & 3 & \\
\hline Ketersediaan prasarana penunjang permukiman & 0 & 2 & 1 & 2 \\
Ketersediaan sarana penunjang permukiman nelayan & 0 & 1 & 2 & 3 \\
Mata pencaharian penduduk & 2 & 0 & 1 & 1 \\
Kondisi bangunan permukiman & 0 & 2 & 1 & 2 \\
Tingkat kepadatan bangunan & 0 & 1 & 2 & 3 \\
Status kepemilikan lahan & 0 & 0 & 3 & 3 \\
Kesesuaian kegiatan berdasarkan rencana peruntukan & 0 & 1 & 2 & 3 \\
Luas Persil Lahan & 0 & 0 & 3 & 3 \\
\hline \hline
\end{tabular}

Variabel-variabel yang berpengaruh berdasarkan hasil berdasarkan hasil skoring yaitu ketersediaan sarana penunjang permukiman nelayan, tingkat kepadatan bangunan permukiman, status kepemilikan lahan permukiman, kesesuaian kegiatan berdasarkan rencana zonasi peruntukan dan luas persil lahan. Selanjutnya variabel-variabel tersebut akan dirumuskan menjadi faktor-faktor. Perumusan variabel menjadi faktor menggunakan teknik analisis theoritical descriptive, berdasarkan kondisi eksisting, kajian pustaka dan hasil wawancara dengan stakeholder.

\section{Merumuskan Skenario Penataan Permukiman Kumuh Dengan Konsep Land Readjustment Di Kelurahan Kedungcowek}

Arahan penataan permukiman kumuh dirumuskan berdasarkan hasil kajian pustaka mengenai konsep land readjustment, karakteristik permukiman kumuh nelayan dan hasil penjaringan aspirasi masyarakat mengenai implementasi konsep land readjustment. Dalam merumuskan arahan penataan permukiman kumuh dengan konsep land readjustment di permukiman kumuh Kedungcowek, metode yang digunakan adalah analisis deskriptif. Perumusan arahan difokuskan per klaster hasil dari pemetaan karakteristik, yaitu klaster 1 dan klaster 2.

Dari karakteristik yang dimiliki klas 1 dan 2, dapat disimpulkan bahwa penataan permukiman kumuh Kedungcowek menggunakan konsep land readjustment pada kedua kluster memiliki penanganan yang berbeda. Dengan keterbatasan lahan yang dimiliki pada persil lahan kluster 1 maka pada kluster ini tidak diberlakukan kontribusi lahan, mekanisme kontribusi lahan lebih tepat diterapkan di klaster 2 dengan kondisi lahan yang lebih luas sehingga memungkinkan dikontribusikannya sebagian lahan untuk kepentingan umum. Untuk mencapai hal tersebut telah dilaksanakan penjaringan preferensi masyarakat terhadap mekanisme persentase konstribusi lahan. Survei ini hanya ditujukan kepada masyarakat pemilik lahan di klaster 2 .

Menurut Peraturan Menteri Perumahan Rakyat no.648-384 tahun 1992, no.739/KPTS/1992, no.09/KPTS/1992 tentang Pedoman Pembangunan Perumahan dan Pemukiman, komposisi fasilitas umum dan permukiman adalah $60 \%$ untuk rumah dan $40 \%$ fasilitas umum. Meski begitu, perbandingan persentase tersebut tergantung luas kompleks permukiman 
yang ada. Untuk permukiman skala kecil, lahan fasilitas umum bisa 20-30 \% dari total lahan. Melihat pembagian lahan pada konsep land readjustment yang berorientasi pada pembagian lahan akhir $60 \%$ untuk permukiman, $30 \%$ fasilitas umum dan $10 \%$ sisanya untuk lahan cadangan, maka dalam penjaringan kesepakatan masyarakat mengenai pembagian lahan dilaksanakan dengan menyebar kuesioner yang didalamnya terdapat pilihan skema pembagian persentase kontribusi lahan yang nantinya masyarakat dapat memilih sesuai dengan kehendak mereka, berikut ketiga pilihan tersebut :

$\checkmark$ Pilihan 1:75\% untuk pemilik lahan dan $25 \%$ untuk kepentingan umum

$\checkmark$ Pilihan $2: 70 \%$ untuk pemilik lahan dan $30 \%$ untuk kepentingan umum

$\checkmark$ Pilihan $3: 60 \%$ untuk pemilik lahan dan $40 \%$ untuk kepentingan umum.

D. Arahan Implementasi Penataan Permukiman dengan Konsep Land Readjustment di Permukiman Kumuh Kelurahan Kedungcowek.

a. Luas Persil Lahan

Dari hasil penjaringan aspirasi dapat diidentifikasi bawah 12 $\%$ pemilik lahan memilih opsi pertama yaitu dengan persentase pembagian lahan $75 \%$ untuk pemilik lahan dan $25 \%$ untuk dikontribusikan, $40 \%$ pemilik lahan memilih opsi kedua dengan pembagian $70 \%$ dari total lahan untuk pemilik lahan dan 30\% untuk dikontribusikan, sedangkan $48 \%$ lainnya memilih opsi ketiga dimana $60 \%$ dari total lahan untuk pemilik lahan dan $40 \%$ sisanya untuk kepentingan umum.

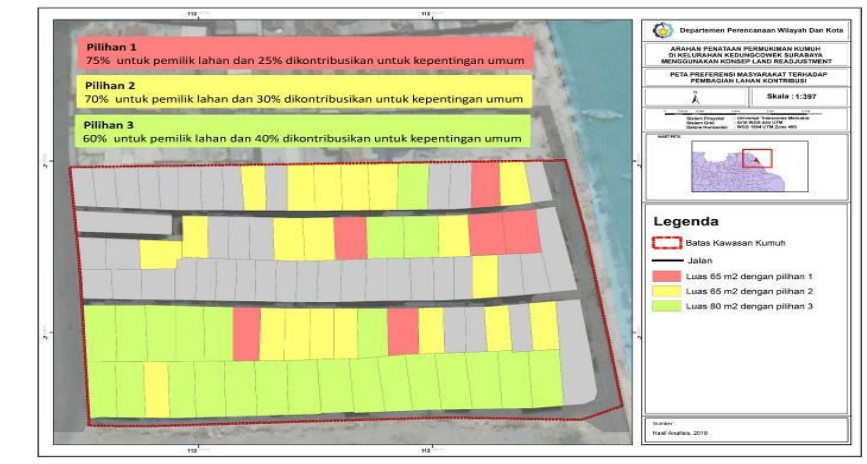

Gambar 3. Preferensi masyarakat terhadap pembagian lahan kontribusi.

Luas persil lahan di permukiman kumuh Kelurahan Kedungcowek klaster 2 terdiri dari luas $65 \mathrm{~m}^{2}$ dan $80 \mathrm{~m}^{2}$. Pada lahan $65 \mathrm{~m}^{2}$ untuk pilihan 1 pemilik lahan mendapatkan lahan seluas $50 \mathrm{~m}^{2}$, untuk pilihan 2 mendapat lahan seluas $45 \mathrm{~m}^{2}$ sedangkan untuk pilihan 3 pemilik lahan hanya mendapat lahan seluas $40 \mathrm{~m}^{2}$. Sedangkan pada lahan seluas $80 \mathrm{~m}^{2}$ untuk pilihan 1 pemilik lahan mendapatkan lahan seluas $60 \mathrm{~m}^{2}$, untuk pilihan 2 mendapat lahan seluas $55 \mathrm{~m}^{2}$ sedangkan untuk pilihan 3 pemilik lahan hanya mendapat lahan seluas $45 \mathrm{~m}^{2}$.

b. Kepadatan Bangunan

Arahan yang dirumuskan pada aspek ini yaitu rekontruksi tata letak bangunan yang akan dibangun diatas lahan permukiman kumuh Kedungcowek. Dengan luas total area lokasi permukiman nelayan Kedungcowek yaitu 0,67 ha. Tutupan lahan yang sebelumnya mencapai $5728 \mathrm{~m}^{2}$ atau $87 \%$ dari total keseluruhan area. Setelah proses land readjustment, bangunan di rekontruksi sehingga tutupan lahannya menjadi $4860 \mathrm{~m}^{2}$ atau hanya $73 \%$ dari total keseluruhan lahan sehingga presentase ruang terbuka meningkat menjadi $27 \%$ atau seluas $1740 \mathrm{~m}^{2}$.

Selain itu pada kondisi faktual permukiman nelayan Kedungcowek teridentifikasi memiliki kepadatan bangunan mencapai 155 unit/ha. Setelah dilakukannya rekontruksi, kepadatan bangunan pada area permukiman tetap dalam angka 155 unit/ha tetapi tata letak bangunan menjadi lebih proposional dan kondisi fisik bangunannya juga sudah permanen semua. Berdasarkan hasil penjaringan pendapat diketahui bahwa masyarakat cenderung memilih bentuk rencana pola permukiman dibangun secara horizontal daripada vertikal, sehingga berdampak pada jumlah bangunan per hektar yang tetap, tetapi perlu diingat bahwa pemanfaatan lahan menjadi lebih efektif dan efisien.

c. Status Kepemilikan Lahan

Arahan yang dirumuskan pada aspek ini yaitu mengenai status kepemilikan lahan hasil land readjustment. Lahan yang ditempati oleh pemilik lahan semua akan berstatus sertifikat hak milik (SHM). Biaya sertifikasi sendiri nantinya dimasukkan dalam skema perhitungan perbedaan antara nilai lahan sebelum dan sesudah rekonstruksi yang akan disesuaikan dengan mekanisme perhitungan dari nilai lahan yang dikontribusikan dan kenaikan nilai lahan yang masih dimiliki oleh para pemilik lahan.

d. Ketersediaan Sarana Penunjang Permukiman Nelayan

Tabel 8.

Pembagian Lahan Untuk Sarana Penunjang Permukiman Sebelum dan Sesudah Proses Land Readjustment

\begin{tabular}{lcccc}
\hline \hline \multirow{2}{*}{ Nama } & \multicolumn{2}{c}{$\begin{array}{c}\text { Sebelum Land } \\
\text { Readjustment }\end{array}$} & \multicolumn{2}{c}{$\begin{array}{c}\text { Sesudah Land } \\
\text { Readjustment }\end{array}$} \\
\cline { 2 - 5 } & Area $\left(\mathrm{m}^{2}\right)$ & Rate (\%) & Area $\left(\mathrm{m}^{2}\right)$ & Rate (\%) \\
\hline Fasilitas Umum & & & & \\
Jalan & 872 & 13,2 & 1440 & 21,8 \\
Ruang Terbuka Hijau & - & - & 75 & 1,1 \\
Balai RW & 117 & 1,7 & 80 & 1,2 \\
Gudang & 80 & 1,2 & 100 & 1,5 \\
Musholla & 80 & 1,2 & - & - \\
Toilet Umum & 25 & 0,4 & 30 & 0,5 \\
Tempat Penjemuran & - & - & 210 & 3,2 \\
Ikan & 96 & 1,5 & 105 & 1,6 \\
Masjid & 1270 & 19,2 & 2040 & 30,9 \\
Total & (A) 5320 & 80,6 & (B) 3990 & 60,5 \\
Lahan Pribadi & - & - & (R) 570 & 8,6 \\
Lahan Cadangan & (s) 10 & 0,2 & - & - \\
Lahan Tidak & 6600 & 100 & 6600 & 100 \\
Ter-Registrasi & & & & \\
Total &
\end{tabular}

Arahan yang dirumuskan yaitu penyediaan lahan sarana prasarana umum yang dapat dialokasikan dari sebagian lahan yang sudah di kontribusikan oleh para pemilik lahan. Selain pengalokasian untuk kebutuhan sarana penunjang profesi nelayan yang disebutkan tadi, pembagian lahan juga mempertimbangkan kebutuhan sarana prasarana umum lain seperti prasarana jalan, fasilitas sosial, sarana peribadatan dan ruang terbuka hijau. Berikut adalah hasil pembagian luas lahan berdasarkan pemenuhan kebutuhan fasilitas sarana prasarana penunjang permukiman kumuh Kedungcowek. 
Dari hasil analisis diatas dapat dilihat peningkatan luas lahan yang diperuntukkan untuk fasilitas umum yang semula seluas $1270 \mathrm{~m}^{2}$ dengan presentasi $19,2 \%$ dari keselurahan total lahan menjadi seluas $2040 \mathrm{~m}^{2}$ dengan presentasi $30,9 \%$ dari seluruh total lahan. Peningkatan luas lahan untuk fasilitas umum tersebut berbanding lurus dengan tercukupinya kebutuhan sarana umum nenunjang permukiman nelayan (tempat penjemuran ikan dan gudang penyimpanan peralatan tangkap nelayan) mengingat sarana ini menjadi poin penting sehingga tidak ada lagi dampak samping dari ketidaktersediannya. Selain itu dengan alokasi pembagian lahan fasilitas umum lain yang lebih proposional, menjadikan permukiman kumuh Kedungcowek ini mengalami peningkatan kualitas lingkungan permukiman.

Pemilihan lokasi pada rencana sarana prasarana juga mempertimbangkan karakteristik aktivitas masyarakat yang ada di lokasi penilitian. Mata pencaharian masyarakat yang mayoritas bermata pencaharian sebagai nelayan membuat aktivitas sehari-hari berpusat pada pesisisr pantai timur. Maka dari itu pada arahan penempatan lokasi, fasilitas umum penunjang profesi nelayan seperti tempat penjemuran ikan dan gudang penyimpanan alat tangkap ikan maupun hasil tangkapan berada berdekatan dengan bibir pantai, mengingat juga perlunya kedekatan dengan dermaga tambatan perahu nelayan.

Selain itu dari hasil pengamatan, aktivitas sosial masyarakat untuk berinteraksi banyak berada di sepanjang jalan di timur sehingga penempatan lokasi balai RW yang berada di timur lokasi permukiman sangat menunjang aktivitas masyarakat untuk berkumpul dan bermain. Untuk memaksimalkan fungsi sarana peribadatan yang sebelumnya terbagi dua, pada rencana penempatan sarana peribadatan di tempatkan di pinggir jalan utama, dengan luas lahan yang lebih besar dari sebelumnya dan lokasi yang mudah dijangkau dari taman surabaya, sentra ikan bulak maupun masyarakat nelayan kedungcowek, maka lokasi ini sangat strategis untuk dibangun fasilitas peribadatan, toilet umum dan ruang terbuka hijau yang juga berfungsi sebagai ruang publik tambahan.

Dilihat dari arus pergerakan orang dan barang. Masyarakat nelayan kedungcowek menjadikan setiap jalan dari timur ke barat menjadi tumpuan pergerakan karena jalur ini menghubungkan antara jalan timur yang menjadi pusat kegiatan ke jalan utama yang berada di sisi barat, maka dari itu tiga jalan yang melintang dari timur ke barat tetap ada, namun dalam rencana perlunya penambahan jalan dari utara ke selatan, selain itu juga adanya pelebaran gang haji ulum menjadi 3,5 meter sesuai standar teknis manajemen proteksi bencana kebakaran sehingga jalan tersebut akan lebih mengefisienkan arus pergerakan serta lebih memudahkan jalur evakuasi dan penanganan jika terjadi bencana.

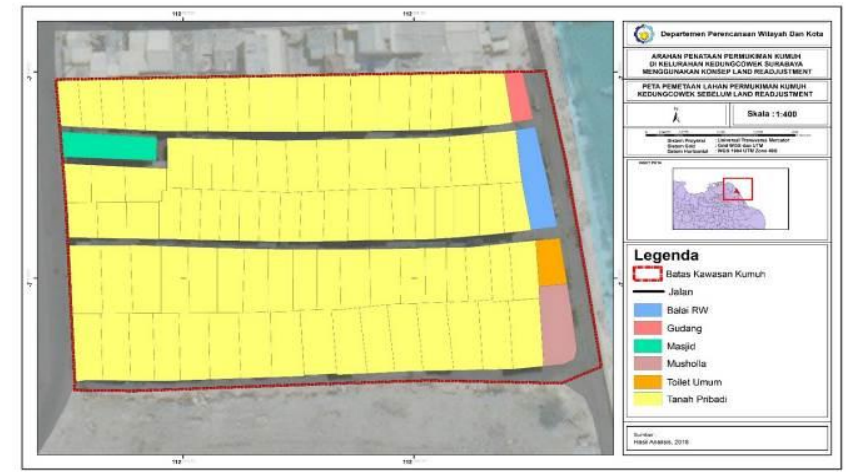

Gambar 4. Peta Eksisting Sebelum Land Readjustment.

Sumber : Hasil Analisis, 2018

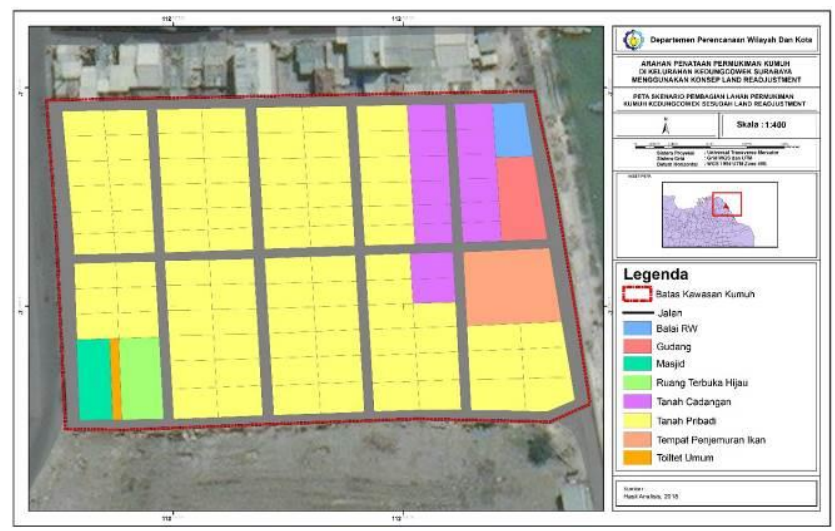

Gambar 5. Peta Rencana Setelah Land Readjustment.

Sumber : Hasil Analisis, 2018

Tabel 9.

Skenario Pembagian Lahan Pada Konsep Land Readjustment

\begin{tabular}{|c|c|c|c|c|c|}
\hline \multicolumn{3}{|c|}{ Total Area Kontribusi Lahan } & \multicolumn{3}{|c|}{ Rasio Kontribusi Lahan } \\
\hline $\begin{array}{c}\text { Untuk } \\
\text { Fasilitas } \\
\text { Umum } \\
\left(\mathrm{m}^{2}\right) \\
\end{array}$ & $\begin{array}{c}\text { Untuk } \\
\text { Lahan } \\
\text { Cadanga } \\
\mathrm{n}\left(\mathrm{m}^{2}\right) \\
\end{array}$ & $\begin{array}{l}\text { Total } \\
\left(\mathrm{m}^{2}\right)\end{array}$ & $\begin{array}{c}\text { Untuk } \\
\text { Fasilitas } \\
\text { Umum } \\
(\%) \\
\end{array}$ & $\begin{array}{l}\text { Untuk Lahan } \\
\text { Cadangan } \\
(\%)\end{array}$ & $\begin{array}{c}\text { Total } \\
\text { Rata-Rata } \\
(\%)\end{array}$ \\
\hline $\begin{array}{c}\mathrm{P}=\mathrm{A}^{\prime}-\mathrm{D} \\
770\end{array}$ & $\begin{array}{c}\mathrm{R} \\
570\end{array}$ & $\begin{array}{c}E=P+R \\
1340\end{array}$ & $\begin{array}{l}\text { P/A' } \\
14,4\end{array}$ & $\begin{array}{l}\mathrm{R} / \mathrm{A}^{\prime} \\
10,7\end{array}$ & $\begin{array}{l}\text { E/A } \\
25,1\end{array}$ \\
\hline \multirow{2}{*}{$\begin{array}{l}\text { Total Lahan } \\
\text { Pribadi } \\
\text { (Sebelum } \\
\text { LR) } \\
\left(\mathrm{m}^{2}\right)\end{array}$} & \multirow{2}{*}{\multicolumn{2}{|c|}{$\begin{array}{c}\text { Total Lahan } \\
\text { Pribadi Termasuk } \\
\text { Lahan Tidak } \\
\text { Ter-Registrasi } \\
\left(\mathrm{m}^{2}\right)\end{array}$}} & \multicolumn{3}{|c|}{$\begin{array}{l}\text { Total Lahan Pribadi } \\
\text { (Setelah LR) } \\
\left(\mathrm{m}^{2}\right)\end{array}$} \\
\hline & & & $\begin{array}{r}\text { Term } \\
\text { Lal } \\
\text { Cadang }\end{array}$ & $\begin{array}{l}\text { Tid } \\
\text { Lah }\end{array}$ & $\begin{array}{l}\text { Termasuk } \\
\text { Cadangan } \\
\left(\mathrm{m}^{2}\right)\end{array}$ \\
\hline $\mathrm{A}$ & & $A+s$ & $\mathrm{D}=\mathrm{H}$ & & B \\
\hline 5320 & & 330 & 45 & & 3990 \\
\hline
\end{tabular}

Sumber : Hasil Analisis,, 2018

\section{KESIMPULAN}

Rumusan masalah dilakukannya penelitian ini yaitu Kekumuhan permukiman Kedungcowek yang ditunjukkan dengan belum jelasnya legalitas lahan hunian, buruknya kondisi fisik bangunan serta masih kurangnya ketersediaan sarana umum penunjang kebutuhan permukiman nelayan yang berdampak pada kondisi prasarana dasar yang tidak sesuai dengan standar teknis penunjang permukiman. Maka dari itu perlunya penataan kembali permukiman kumuh menggunakan konsep land readjustment.

Berdasarkan analisis-analisis yang telah dilaksanakan, dapat dirumuskan arahan penataan permukiman kumuh di 
Kedungcowek dengan menggunakan konsep Land Readjustment. Berikut arahan yang dapat dirumuskan :

1.Lahan baru yang akan ditempati oleh pemilik lahan semua akan berstatus sertifikat hak milik (SHM). Biaya sertifikasi sendiri nantinya dimasukkan dalam skema perhitungan perbedaan antara nilai lahan sebelum dan sesudah rekonstruksi serta relokasi sementara yang akan disesuaikan dengan mekanisme perhitungan dari nilai lahan yang dikontribusikan dan kenaikan nilai lahan yang masih dimiliki oleh para pemilik lahan.

2. Rekonstruksi bangunan yang membuat tutupan lahan menjadi $4860 \mathrm{~m}^{2}$ atau hanya $73 \%$ dari total keseluruhan area, hal itu berdampak pada presentase ruang terbuka meningkat menjadi $27 \%$ atau seluas $1740 \mathrm{~m}^{2}$. Berdasarkan hasil penjaringan pendapat diketahui juga bahwa masyarakat cenderung memilih bentuk rencana pola permukiman dibangun secara horizontal daripada vertikal, sehingga berdampak pada jumlah bangunan per hektar yang tetap. Meskipun kepadatan bangunan pada area permukiman tetap dalam angka 155 unit/ha tetapi tata letak bangunan menjadi lebih proposional dan kondisi fisik bangunannya sudah permanen semua.

3. Mekanisme pembagian lahan terdiri dari tiga pilihan yang didapatkan dari kesepakatan dengan pemilik lahan. Adapun ketiga opsi tersebut $75 \%$ untuk pemilik lahan dan 25\% untuk kepentingan umum, $70 \%$ untuk pemilik lahan dan $30 \%$ untuk kepentingan umum, serta $60 \%$ untuk pemilik lahan dan $40 \%$ untuk kepentingan umum.

4. Setelah adanya kontribusi lahan dari masyarakat, terjadi peningkatan luas lahan yang diperuntukkan untuk fasilitas umum yang semula seluas $1270 \mathrm{~m}^{2}$ seluas $2040 \mathrm{~m}^{2}$ dengan presentasi 30,9\% dari seluruh total lahan. Peningkatan luas lahan untuk fasilitas umum tersebut berbanding lurus dengan tercukupinya kebutuhan sarana umum nenunjang permukiman nelayan (tempat penjemuran ikan dan gudang penyimpanan peralatan tangkap nelayan) mengingat sarana ini menjadi poin penting sehingga tidak ada lagi dampak samping dari ketidaktersediannya.

5. Dari hasil skenario pembagian lahan juga didapat lahan cadangan seluas $8,6 \%$ dari total lahan yang nantinya dapat dimanfaatkan untuk dijual atau disewakan, keuntungan dari hasil tersebut diharapkan dapat menutup biaya keseluruhan pembangunan.

\section{DAFTAR PUSTAKA}

[1] Badan Pusat Statistik Provinsi Jawa Timur, "Provinsi Dalam Angka 2016."

[2] E. Barbara, Patrica Bela. Ummilia, "Clustering Permukiman Kumuh di Kawasan Pusat Kota Surabaya," J. Tek. POMITS, vol. 3, no. 2, 2014.

[3] Kementrian Pekerjaan Umum dan Perumahan Rakyat Direktorat Jenderal Cipta Karya, "Kota Tanpa Kumuh,” 2017.

[4] Badan Perencanaan dan Pembangunan Kota Surabaya, "RKP-KP Kota Surabaya," Surabaya, 2015.

[5] R. Archer, "Introducing the urban land pooling/readjustment technique into Thailand to improve urban development and land supply," Thailand, 1992

[6] W. A. Doebele, Land readjustment: A different approach to financing urbanization. Lexington, MA: Lexington Books, 1982.

[7] R. Yukeiko and D. Rahmawati, "Konsep Land Sharing Sebagai Alternatif Penataan Permukiman Nelayan di Kelurahan Gunung Anyar Tambak Surabaya," J. Tek. ITS, vol. 4, no. 2, 2015. 